\title{
Biology and interactions of two distinct monopartite begomoviruses and betasatellites associated with radish leaf curl disease in India
}

\author{
AK Singh ${ }^{1,2}$, B Chattopadhyay ${ }^{1}$ and S Chakraborty ${ }^{1 *}$
}

\begin{abstract}
Background: Emerging whitefly transmitted begomoviruses are major pathogens of vegetable and fibre crops throughout the world, particularly in tropical and sub-tropical regions. Mutation, pseudorecombination and recombination are driving forces for the emergence and evolution of new crop-infecting begomoviruses. Leaf curl disease of field grown radish plants was noticed in Varanasi and Pataudi region of northern India. We have identified and characterized two distinct monopartite begomoviruses and associated beta satellite DNA causing leaf curl disease of radish (Raphanus sativus) in India.
\end{abstract}

Results: We demonstrate that RaLCD is caused by a complex of two Old World begomoviruses and their associated betasatellites. Radish leaf curl virus-Varanasi is identified as a new recombinant species, Radish leaf curl virus (RaLCV) sharing maximum nucleotide identity of $87.7 \%$ with Tomato leaf curl Bangladesh virus[Bangladesh:2] (Accession number AF188481) while the virus causing radish leaf curl disease-Pataudi is an isolate of Croton yellow vein mosaic virus-[India] (CYVMV-IN) (Accession number AJ507777) sharing 95.8\% nucleotide identity. Further, RDP analysis revealed that the RaLCV has a hybrid genome, a putative recombinant between Euphorbia leaf curl virus and Papaya leaf curl virus. Cloned DNA of either RaLCV or CYVMV induced mild leaf curl symptoms in radish plants. However, when these clones (RaLCV or CYVMV) were individually co-inoculated with their associated cloned DNA betasatellite, symptom severity and viral DNA levels were increased in radish plants and induced typical RaLCD symptoms. To further extend these studies, we carried out an investigation of the interaction of these radish-infecting begomoviruses and their associated satellite, with two tomato infecting begomoviruses (Tomato leaf curl Gujarat virus and Tomato leaf curl New Delhi virus). Both of the tomato-infecting begomoviruses showed a contrasting and differential interaction with DNA satellites, not only in the capacity to interact with these molecules but also in the modulation of symptom phenotypes by the satellites.

Conclusion: This is the first report and experimental demonstration of Koch's postulate for begomoviruses associated with radish leaf curl disease. Further observations also provide direct evidence of lateral movement of weed infecting begomovirus in the cultivated crops and the present study also suggests that the exchange of betasatellites with other begomoviruses would create a new disease complex posing a serious threat to crop production.

Keywords: Radish, Begomovirus, Leaf curl, Interaction, Novel species, India

\footnotetext{
* Correspondence: supriyachakrasls@yahoo.com

${ }^{1}$ Molecular Virology Laboratory, School of Life Sciences, Jawaharlal Nehru

University, New Delhi 110 067, India

Full list of author information is available at the end of the article
} 


\section{Background}

Geminiviruses (family Geminiviridae) have circular single stranded DNA genomes that are encapsidated in twinned quasi-isometric particles and are classified into four genera: Begomovirus, Mastrevirus, Curtovirus and Topocuvirus [1,2]. The largest genus, Begomovirus comprise of viruses transmitted by whitefly (Bemisia tabaci Genn.). Begomoviruses are assumed to have been coevolving with their hosts for a long time, however, it is in the past two decades, these viruses have become an economically important plant pathogens [3-5]. These viruses contain genomes consisting of either one or two similar-size DNA components [6]. The DNA-A component encodes all viral functions required for replication, control of gene expression, encapsidation and vector transmission $[7,8]$. The DNA-B, code for two proteins which are involved in movement of the virus between and within plant cells [6]. Both components of bipartite begomoviruses are required for systemic infection and symptom induction [9]. In contrast, monopartite begomoviruses such as isolates of Tomato yellow leaf curl virus, Tomato leaf curl virus and Cotton leaf curl Multan virus [10-13] possess only a single genomic component resembling DNA-A, which alone is capable of inducing disease symptoms. However, for some other monopartite begomoviruses like Ageratum yellow vein virus, Bhendi yellow vein mosaic virus, Cotton leaf curl Multan virus, Eupatorium yellow vein virus, Tomato yellow leaf curl China virus and Cotton leaf curl Gezira virus, association of betasatellite (DNA- $\beta$ ) has been found to be essential for the induction of typical disease symptoms [14-19]. Betasatellite is a circular, singlestranded DNA molecule of $\sim 1.35 \mathrm{~kb}$ length with a single open-reading frame (ORF) $\beta C 1$, an adenine-rich region, a satellite conserved region having nonanulceotides (TAATATTAC) and it shares negligible sequence similarity with either DNA-A or DNA-B of bipartite begomoviruses [20-22].

Radish (Raphanus sativus L.; Family-Brassicaceae) is an important vegetable crop grown throughout India. Leaf curl disease of radish (RaLCD), for the first time, was reported from Punjab province of Pakistan [23]. In India, RaLCD was first reported from a homestead garden and adjoining farmer's field near Varanasi [24]. Later, RaLCD was also observed in Pataudi, Haryana, India. The infected plants remain stunted and leaves exhibited both upward and downward curling along with conspicuous vein enations.

In the present study, we have characterized two distinct begomoviruses and betasatellites associated with plants showing symptoms of RaLCD in Varanasi and Pataudi, India. These begomovirus species, together with the betasatellite can induce RaLCD. We further demonstrate the complexity of the interactions between RaLCD-associated satellites with radish and tomatoinfecting begomoviruses indicating co-adaptation of weed infecting begomovirus in cultivated crop species like radish, hitherto a non-host.

\section{Results}

Cloning and genome organization of two begomovirus species associated with RaLCD in India

RaLCD symptoms developed on grafted Raphanus sativus plants were identical to those of naturally infected plants. The initial symptoms appeared as downward curling on the young leaves about 3-4 weeks after grafting, later infected leaves exhibited typical upward and downward leaf curling, enation on adaxial side and stunted growth of plants, which also failed to bear any flower. Southern blot hybridization and PCR based detection using begomoviruses specific primers [25] revealed association of begomovirus with RaLCD infected plants from Varanasi, Uttar Pradesh and Pataudi, Haryana in India. Full-length $(\sim 2.7 \mathrm{~kb})$ viral genome from both samples (Cholapur and Pataudi) were cloned. Several putative full-length clones were obtained and preliminary restriction analysis indicated the presence of single class of molecule in both samples (data not shown). Two fulllength molecules from each sample were selected and sequenced. The complete sequence of RaLCD-associated-Varanasi virus (GenBank EF175733) and RaLCDassociated-Pataudi virus (GenBank FJ593629) isolate were of 2756 nucleotides (nt) and 2759 nt, respectively. The genome organization of both the isolates was similar to that of Old World monopartite begomoviruses [i.e. two virus-sense ORFs (V1 and V2) and four complementary-sense ORFs (C1, C2, C3, C4)]. Intergenic region (IR) sequences ( $290 \mathrm{nt})$ contained conserved nonanucleotide sequence, putative Rep $(\mathrm{C} 1)$ protein binding sites and the TATA box. The nucleotide identity of full-length genome and IR sequences between RaLCD-associated-Varanasi and RaLCD-associated-Pataudi were 79.6 and $71.6 \%$, respectively, indicating involvement of two distinct species (Table 1).

The sequence of the begomovirus DNA component of the RaLCD-associated-Varanasi virus had maximum nucleotide identity with Tomato leaf curl Bangladesh virus-[Bangladesh:2] (ToLCBDV-[BD:2]) ( 87.7\%) (Table $1)$. Phylogenetic analysis also support that RaLCD-associated-Varanasi is a distinct species, having very low bootstrap values with the Euphorbia leaf curl virus[China:Guangxi 35:2002] (EuLCV-[CN:Gx35:02]) (Figure 1). Thus, RaLCD-associated-Varanasi virus is an isolate of a new begomovirus species, and the name Radish leaf curl virus-[India:Varanasi:2005] (RaLCV-[IN:Var:05]) is given following (ICTV) guidelines [2]. 
Table 1 Nucleotide identities (\%) for full-length genome (nt) and IR and amino acid (aa) sequence identities (\%) for ORFs of two begomoviruses associated with RaLCD in India and selected previously characterized begomoviruses

\begin{tabular}{|c|c|c|c|c|c|c|c|c|}
\hline Begomoviruses & $\begin{array}{l}\text { DNA- } \\
\mathrm{A}\end{array}$ & Rep & TrAP & REn & AC4 & $\mathrm{CP}$ & AV2 & ICR \\
\hline \multicolumn{9}{|l|}{ RaLCV-[IN:Var:05] } \\
\hline$\overline{\text { ToLCBDV-[BD:2] }}$ & 87.7 & 84.8 & 80.6 & 86.6 & 54.6 & 94.1 & 98.8 & 75.3 \\
\hline TbCSV-[CN:Yn35:01] & 87.0 & 84.5 & 87.3 & 88.1 & 50.5 & 93.9 & 99.2 & 71.2 \\
\hline$\overline{A E V-[N P: 01]}$ & 86.9 & 84.5 & 85.8 & 88.1 & 65.9 & 93.9 & 98.4 & 74.0 \\
\hline $\begin{array}{l}\text { TbCSV-[CN:Yn282: } \\
\text { Age:03] }\end{array}$ & 86.9 & 83.9 & 88.1 & 88.1 & 48.0 & 93.0 & 99.2 & 71.2 \\
\hline PaLCuV-IN[IN:LuC] & 86.4 & 73.6 & 96.3 & 97.0 & 44.7 & 91.5 & 97.7 & 58.0 \\
\hline $\begin{array}{l}\text { CLCuKV } \\
\text { M806b:c }\end{array}$ & 85.8 & 87.5 & 84.3 & 82.8 & 66.0 & 96.6 & 98.8 & 40.2 \\
\hline EuLCV-[CN:GX35:02] & 85.7 & 90.0 & 82.1 & 88.1 & 86.5 & 78.0 & 93.8 & 69.7 \\
\hline ChiLCV-IN[IN::05] & 84.0 & 86.4 & 82.1 & 73.1 & 52.9 & 98.8 & 89.3 & 75.3 \\
\hline $\begin{array}{l}\text { ChiLCV-Mul[PK: } \\
\text { Mul:98] }\end{array}$ & 83.0 & 84.5 & 79.4 & 80.6 & 53.6 & 87.3 & 96.1 & 64.4 \\
\hline$\overline{\text { ToLCGV-[IN:Var:01] }}$ & 80.7 & 83.1 & 79.9 & 77.6 & 51.0 & 86.1 & 80.9 & 68.4 \\
\hline CYVMV-[IN] & 80.4 & 75.9 & 83.6 & 87.3 & 48.2 & 87.3 & 83.2 & 59.1 \\
\hline BYVMV-IN[IN:Mad] & 74.9 & 81.2 & 64.9 & 67.9 & 69.6 & 70.3 & 93.4 & 38.7 \\
\hline $\begin{array}{l}\text { ToLCNDV-IN[IN:ND: } \\
\text { Svr:92] }\end{array}$ & 74.2 & 77.8 & 60.4 & 66.4 & 62.1 & 73.2 & 93.0 & 60.0 \\
\hline $\begin{array}{l}\text { SLCCNV-IN[IN:LuC: } \\
\text { Pum] }\end{array}$ & 73.6 & 75.6 & 57.5 & 64.8 & 53.5 & 71.4 & 93.0 & 40.3 \\
\hline $\begin{array}{l}\text { MYMIV-[IN:ND: } \\
\text { Bg3:91] }\end{array}$ & 63.5 & 70.6 & 52.2 & 40.2 & 45.5 & 50.0 & 72.2 & 10.9 \\
\hline
\end{tabular}

Bg3:91]

\section{CYVMV-[IN:Pat:}

Rad:08]

\begin{tabular}{|c|c|c|c|c|c|c|c|c|}
\hline RaLCV & 79.6 & 75.6 & 82.8 & 89.6 & 44.7 & 83.2 & 87.3 & 71.6 \\
\hline ToLCBDV-[BD:2] & 80.1 & 77.0 & 85.8 & 84.3 & 54.6 & 82.8 & 91.5 & 67.5 \\
\hline TbCSV-[CN:Yn35:01] & 80.0 & 76.7 & 77.6 & 85.1 & 35.3 & 83.2 & 92.2 & 71.3 \\
\hline AEV-[NP:01] & 80.9 & 77.8 & 79.9 & 86.6 & 52.9 & 82.4 & 91.3 & 70.5 \\
\hline $\begin{array}{l}\text { TbCSV-[CN:Yn282: } \\
\text { Age:03] }\end{array}$ & 79.9 & 76.2 & 78.4 & 85.1 & 34.1 & 83.2 & 91.3 & 71.3 \\
\hline PaLCuV-IN[IN:Luc] & 86.0 & 92.2 & 81.3 & 88.1 & 95.3 & 82.4 & 97.7 & 59.7 \\
\hline $\begin{array}{l}\text { CLCuKV-Man[PK: } \\
\text { M806b:96] }\end{array}$ & 78.1 & 75.0 & 86.6 & 87.3 & 44.7 & 83.6 & 98.8 & 54.5 \\
\hline EuLCV-[CN:GX35:02] & 78.1 & 77.7 & 85.8 & 88.8 & 45.9 & 79.7 & 72.9 & 73.3 \\
\hline ChiLCV-IN[IN:05] & 78.4 & 77.3 & 82.1 & 77.6 & 35.3 & 82.4 & 89.0 & 70.1 \\
\hline $\begin{array}{l}\text { ChiLCV-Mul[PK: } \\
\text { Mul:98] }\end{array}$ & 78.3 & 76.5 & 82.4 & 84.3 & 31.8 & 82.0 & 83.1 & 74.6 \\
\hline ToLCGV-[IN:Var:01] & 80.5 & 76.5 & 83.6 & 81.3 & 35.3 & 96.5 & 85.2 & 66.9 \\
\hline CYVMV-[IN] & 95.8 & 94.7 & 96.3 & 93.3 & 90.6 & 100 & 98.3 & 94.4 \\
\hline BYVMV-IN[IN:Mad] & 71.3 & 70.0 & 64.2 & 71.6 & 40.0 & 80.5 & 66.9 & 54.2 \\
\hline $\begin{array}{l}\text { ToLCNDV-IN[IN:ND: } \\
\text { Svr:92] }\end{array}$ & 71.5 & 69.5 & 64.9 & 64.2 & 34.5 & 82.8 & 68.8 & 64.2 \\
\hline $\begin{array}{l}\text { SLCCNV-IN[IN:Var: } \\
\text { Pum] }\end{array}$ & 70.8 & 67.3 & 60.4 & 68.0 & 37.9 & 81.2 & 67.0 & 61.5 \\
\hline $\begin{array}{l}\text { UYMIV-[IN:ND: } \\
\text { 3g3:91] }\end{array}$ & 62.0 & 65.8 & 50.0 & 40.2 & 30.6 & 74.1 & 47.3 & 46.2 \\
\hline
\end{tabular}

However, RaLCD-associated-Pataudi virus sequence was $95.8 \%$ identical to Croton yellow vein mosaic virus[India] (CYVMV-[IN]) isolates (Table 1) and therefore, it can be considered as a variant of CYVMV-[IN] and designated as Croton yellow vein mosaic virus-[India: Pataudi:Radish:2008].

The predicted amino acid sequences of the ORFs of RaLCV-[IN:Var:05] were compared to those of other begomoviruses. TrAP, REn, CP and AV2 of RaLCV-[IN: Var:05] showed maximum amino acid identity (91-98\%; Table 1) with Papaya leaf curl virus-India [India:Lucknow] (PaLCuV-IN[IN:Luc]) with which full-length DNA-A shared $86.4 \%$ identity (Table 1). However, AC4 and Rep shared maximum amino acid (aa) identity (86.5\% and $90 \%$, respectively) (Table 1 ) with weedinfecting begomovirus, EuLCV-[CN:Gx35:02]. Interestingly, IR of DNA-A showed maximum identity with ToLCBDV-[BD:2] (75.3\%) (Table 1). Such divergence in the amino acid sequence of the encoded proteins present strong evidence of recombination in the genome of RaLCV-[IN:Var:05]. Sequences of the CYVMV-[IN:Pat: Rad:08] V1 (CP), V2, C1 (Rep), C2, C3 and IR ORFs were generally >95\% [nt and aa] identical with CYVMV-[IN], whereas maximum identity of C4 sequences (90\% nt and $85 \%$ aa) were with PaLCuV-IN [IN:Luc] (Table 1).

A multiple alignment of the IR of six begomoviruses revealed that RaLCV-[IN:Var:05] and ToLCBDV-[BD:2] share very related iterons sequence (GGTGA-AC/TGGTAC) whereas CYVMV-[IN:Rad:Pat:08] and CYVMV-IN iterons sequences were identical (GGGGACTC-GGGGGA) (data not shown). The major difference between the RaLCV-[IN:Var:05] and ToLCBDV-[BD:2] was found in spacer sequence of two iterons, as RaLCV[IN:Var:05] contains AC while ToLCBDV-[BD:2] contains AT. A third iteron was present in 5' end of the intergenic common region (ICR) of RaLCV. Noticeably, besides $\mathrm{GC}$ rich region, stem loop region and the TATA Box were conserved for all geminiviruses and all the viruses tested here shared two short sequences, AATGGCA and TAAT, located at the 5'end of the region between TATA box and stem-loop.

\section{Cloning of betasatellite DNAs and genome organization}

Despite repeated attempts, we could not identify any DNA-B molecule from the infected samples, indicating monopartite nature of virus isolates. Full-length genome $(\sim 1.3 \mathrm{~kb})$ of betasatellites was cloned from both (Varanasi and Pataudi) RaLCD samples using universal primers [26]. The complete nucleotide sequence of betasatellites associated with RaLCV-[IN:Var:05] and CYVMV-[IN:Pat:Rad:08] was determined as $1358 \mathrm{nt}$ (GenBank Accession no EF175734) and 1367 nt (GenBank Accession no. FJ593630), respectively. These two 


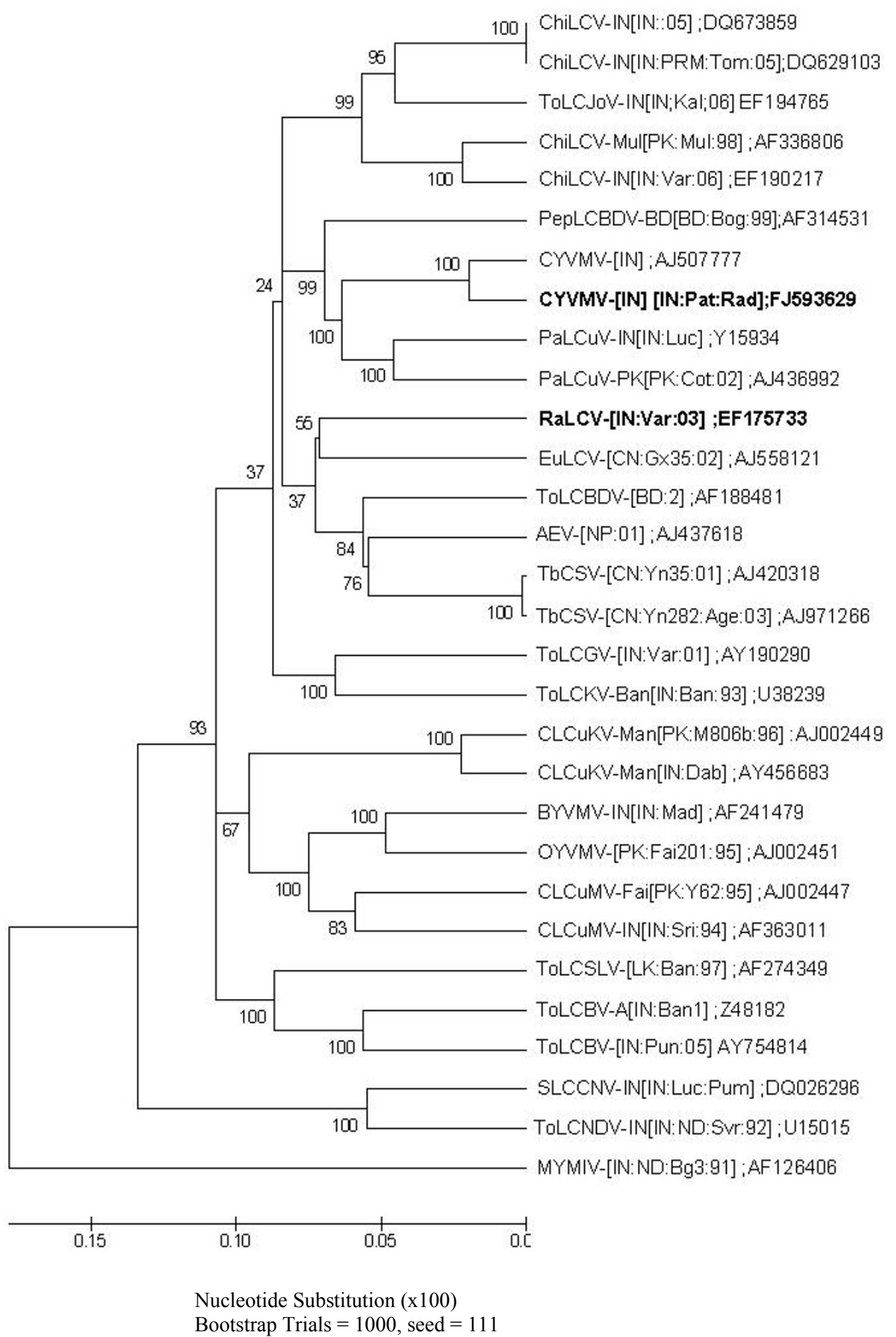

Figure 1 Phylogenetic relationship of full-length DNA-A of radish-infecting begomoviruses with other begomoviruses. Phylogenetic tree was generetaed based on aligned complete DNA-A sequences using ClustalW. All the sequences were obtained from GenBank. The viruses understudy are indicated as bold.

betasatellites had structural features similar to those of other betasatellites i.e. a single ORF $\beta C 1$, satellite conserved region (SCR) and A rich region. The complete nucleotide sequence identity between RaLCV-[IN: Var:05] and CYVMV-[IN:Pat:Rad:08] was 63.2\%, indicating that these are distinct betasatellite species. The 
complete sequence of DNA betasatellite associated with RaLCV-[IN:Var:05] and CYVMV-[IN:Pat:Rad:08] shared maximum nucleotide identity with Tobacco leaf curl betasatellite [Pakistan:Rahim Yar Khan:1998] (TbLCB[PK:RYK:98]) (83\%) and Croton yellow vein mosaic betasatellite [Pakistan:Punjab:2006] (CroYVMB-[PK: Pun:06]) (91.1\%), respectively (Table 2). Phylogenetically, RaLCV-[IN:Var:05] associated DNA betasatellite clusterd with the one associated with tobacco disease with TbLCB-[PK:RYK:98], whereas the CYVMV-[IN:Pat: Rad:08] associated DNA betasatellite clustered with another isolate of this species. (Figure 2).

ORF $\beta$ C1 of RaLCB-[IN:Var:05] and CYVMB-[IN:Pat: Rad:08] showed maximum nucleotide identity with TbLCB-Pak-[NIB 12-1] (89.1\%) and CroYVMB-[PK: Pun:06] (93.8\%), respectively (Table 2). Similarly, ORF $\beta C 1$ encoded protein of RaLCV-[IN:Var:05] and

Table 2 Per cent identity (nucleotide) among DNA- $\beta$ of two Radish leaf curl virus isolates and with selected begomoviruses originating in Asia

\begin{tabular}{llll}
\hline Beta & Percent & C1 & SCR \\
\hline TbLCB- Radish & & & \\
\hline TbLCB-[PK:RYK:98] & $\mathbf{8 3 . 0}$ & $\mathbf{8 9 . 1 ( 8 1 . 1 )}$ & $\mathbf{8 4 . 4}$ \\
\hline ToLCB-[IN:Var:06] & 72.7 & $79.3(76.3)$ & $\mathbf{9 3 . 2}$ \\
\hline TYLCTHB-[IN:Aur:06] & 72.3 & $76.6(75.0)$ & $\mathbf{9 3 . 0}$ \\
\hline AYVSLB-[IN:Mad:03] & 68.2 & $75.9(71.2)$ & $\mathbf{9 0 . 0}$ \\
\hline TbCSB-[CN:Yn115:02] & 67.2 & $68.2(68.6)$ & $\mathbf{9 3 . 9}$ \\
\hline ToYLCCNB-[CN:Yn261:02] & 66.2 & $69.6(61.9)$ & $\mathbf{9 0 . 8}$ \\
\hline AYLCuB-[PK:Fai3:94] & 66.0 & $72.6(56.5)$ & $\mathbf{9 4 . 3}$ \\
\hline CroYVMB-[PK:Pun:06] & 62.5 & $62.6(57.5)$ & $\mathbf{9 1 . 7}$ \\
\hline ToLCB-[IN:ND:02 & 62.0 & $72.1(66.9)$ & $\mathbf{8 0 . 3}$ \\
\hline PaLCuB-[IN:Chi:05] & 61.3 & $64.5(59.8)$ & $\mathbf{8 5 . 5}$ \\
\hline PaLCUB-[IN:Jab:03] & 61.2 & $65.7(61.9)$ & 64.4 \\
\hline ToLCB-[IN:CP:04] & 61.1 & $70.8(66.9)$ & $\mathbf{8 4 . 1}$ \\
\hline CYVMB-Radish & & & \\
\hline RaLCB-Var & 63.2 & $64.7(61.9)$ & $\mathbf{9 0 . 8}$ \\
\hline TbLCB-[PK:RYK:98] & 60.4 & $65.0(61.0)$ & $\mathbf{8 3 . 8}$ \\
\hline ToLCB-[IN:Var:06] & 62.4 & $64.7(57.6)$ & $\mathbf{9 1 . 9}$ \\
\hline TYLCTHB-[IN:Aur:06] & 61.8 & $65.0(56.8)$ & $\mathbf{9 0 . 8}$ \\
\hline AYVSLB-[IN:Mad:03] & 59.7 & $66.7(60.2)$ & $\mathbf{8 8 . 2}$ \\
\hline TbCSB-[CN:Yn115:02] & 59.8 & $63.3(57.6)$ & $\mathbf{9 1 . 2}$ \\
\hline ToYLCCNB-[CN:Yn261:02] & 60.0 & $64.7(60.2)$ & $\mathbf{8 6 . 4}$ \\
\hline AYLCuB-[PK:Fai3:94] & 62.3 & $66.0(62.3)$ & $\mathbf{9 0 . 8}$ \\
\hline CroYVMB-[PK:Pun:06] & $\mathbf{9 1 . 1}$ & $\mathbf{9 3 . 8}(\mathbf{9 0 . 7 )}$ & $\mathbf{9 5 . 6}$ \\
\hline ToLCB-[IN:ND:02] & 59.8 & $65.8(61.0)$ & $\mathbf{8 5 . 9}$ \\
\hline PaLCUB-[IN:Chi:05] & 60.8 & $70.9(66.9)$ & $\mathbf{8 7 . 6}$ \\
\hline PaLCuB-[IN:Jab:03] & 61.3 & $71.4(66.1)$ & $\mathbf{8 4 . 1}$ \\
\hline ToLCB-[IN:CP:04] & 59.8 & $63.9(61.0)$ & $\mathbf{8 5 . 8}$ \\
\hline
\end{tabular}

Figures in bracket indicate putative deduced amino acid sequence identity. *Identity over $80 \%$ is Bold
CroYVMB-[IN:Pat:Rad:08] associated DNA betasatellite showed maximum identity with TbLCB-Pak-[NIB 121] and CroYVMB-[PK:Pun:06] (87.3\% and 90.7\%, respectively) (Table 2). The conserved ORF $\beta C 1$ of RaLCB-[IN:Var:05] and CroYVMB-[IN:Pat:Rad:08] encoded a $13.7 \mathrm{kDa}$ protein. The nucleotide sequences of SCR of RaLCV-[IN:Var:05] and CYVMV-[IN:Pat: Rad:08] associated DNA betasatellite showed > 90\% identity with those of other DNA betasatellites (Table 2). SCR of RaLCV-[IN:Var:05] associated DNA betasatellite and CYVMV-[IN:Pat:Rad:08] associated DNA betasatellite showed maximum identity with $\mathrm{AYLCuB}$ (94.3\%) and CroYVMB-[PK:Pun:06] (95.6\%), respectively (Table 2).

\section{Detection of recombination}

RaLCV-[IN:Var:05] (RLA) and CYVMV-[IN:Pat:Rad:08] (CRA) genomes were analyzed using two independent methods (simplot graph, and RDP analysis) and the results indicated definite evidence of recombination within RaLCV-[IN:Var:05] genome (Figure 3). In RaLCV-[IN:Var:05], two significant breakpoints detected at nts 725 and 1549 with significant 'P value' (0.01) (Figure $3 \mathrm{c}$ ), corresponding to the region of the genome with $>90 \%$ identity with the sequence of PaLCuV. The $\mathrm{N}$ terminal amino acid sequence of Rep was most similar to EuLCV (87\%) than other geminiviruses. Evidence of recombination with EuLCV like virus was found within Rep coding region (from nt 2154 to 2519). Bootscan and Simplot analysis also supported these observations (Figure $3 \mathrm{a}, \mathrm{b})$. To confirm recombinant nature of RaLCV[IN:Var:05] genome, dendrograms were also generated based on nucleotide sequence of virion sense ORF (AV1), complimentary sense ORFs (AC1, AC2 and AC3) with that of related begomoviruses. Interestingly, RaLCV-[IN:Var:05] clustered with PaLCuV when AV1, $A C 2$ and $A C 3$ sequences were used for phylogenetic analysis, whereas RaLCV-[IN:Var:05] was placed with EuLCV in the same clade in the dendrogram generated using $\mathrm{AC} 1$ nucleotide sequences (data not shown).

To detect possible evidence of recombination in the CYVMV-[IN:Pat:Rad:08] genome, Simplot and RDP analysis were performed with begomoviruse bearing the closest identity viz., CYVMV-[IN], and with two tomatoinfecting begomoviruses viz., Tomato leaf curl Gujarat virus-[India:Varanasi:2001] (ToLCGV-[IN:Var:01]) and Tomato leaf curl New Delhi virus-India [India:New Delhi:Severe:1992] (ToLCNDV- [IN:ND:Svr:92]). Simplot and RDP analyses revealed that this is not a recombinant virus; rather it is a derivative of CYVMV-[IN]. Similarly, simplot and RDP analysis carried out for betasatellite molecules DNAs (RaLCB-[IN:Var:05] and CroYVMB-[IN:Pat:Rad:08]) could not reveal any evidence of recombination. 


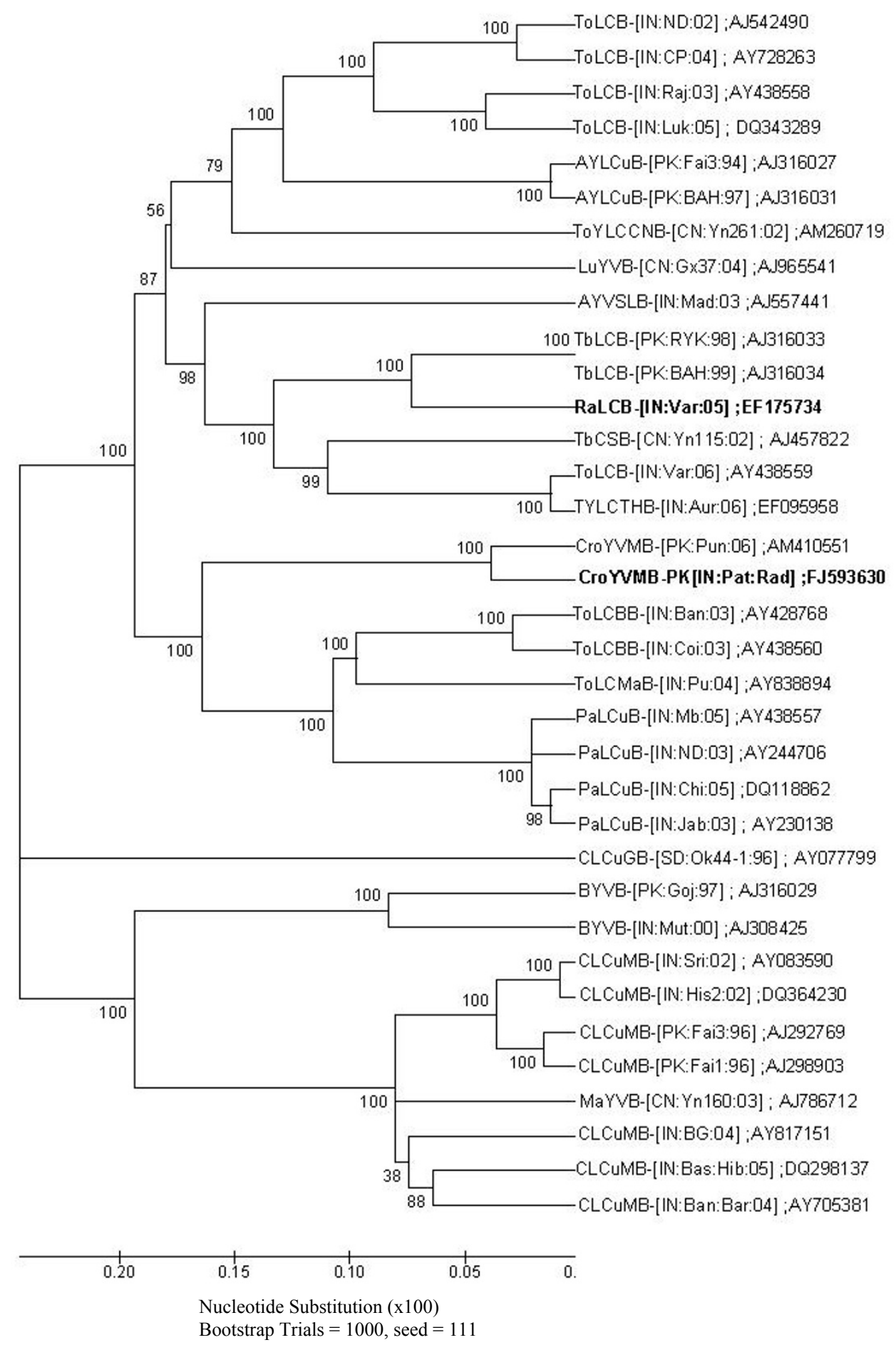

Figure 2 Phylogenetic relationship of RaLCB and CroYVMB with betasatellites associated with other begomoviruses. Phylogenetic tree was geenerated based on alignment of complete genome sequences using ClustalW. The viruses understudy are indicated as bold.

\section{Infectivity of cloned DNAs}

Partial tandem repeats of DNA-A and DNA betasatellite were constructed in binary vector and their infectivity were tested (either alone or together in combination) onto radish, tomato and $N$. benthamiana plants by agroinoculation. Radish plants co-inoculated with RLA + RL $\beta$ developed systemic symptoms including downward leaf curling within 20 days post inoculation (dpi) 


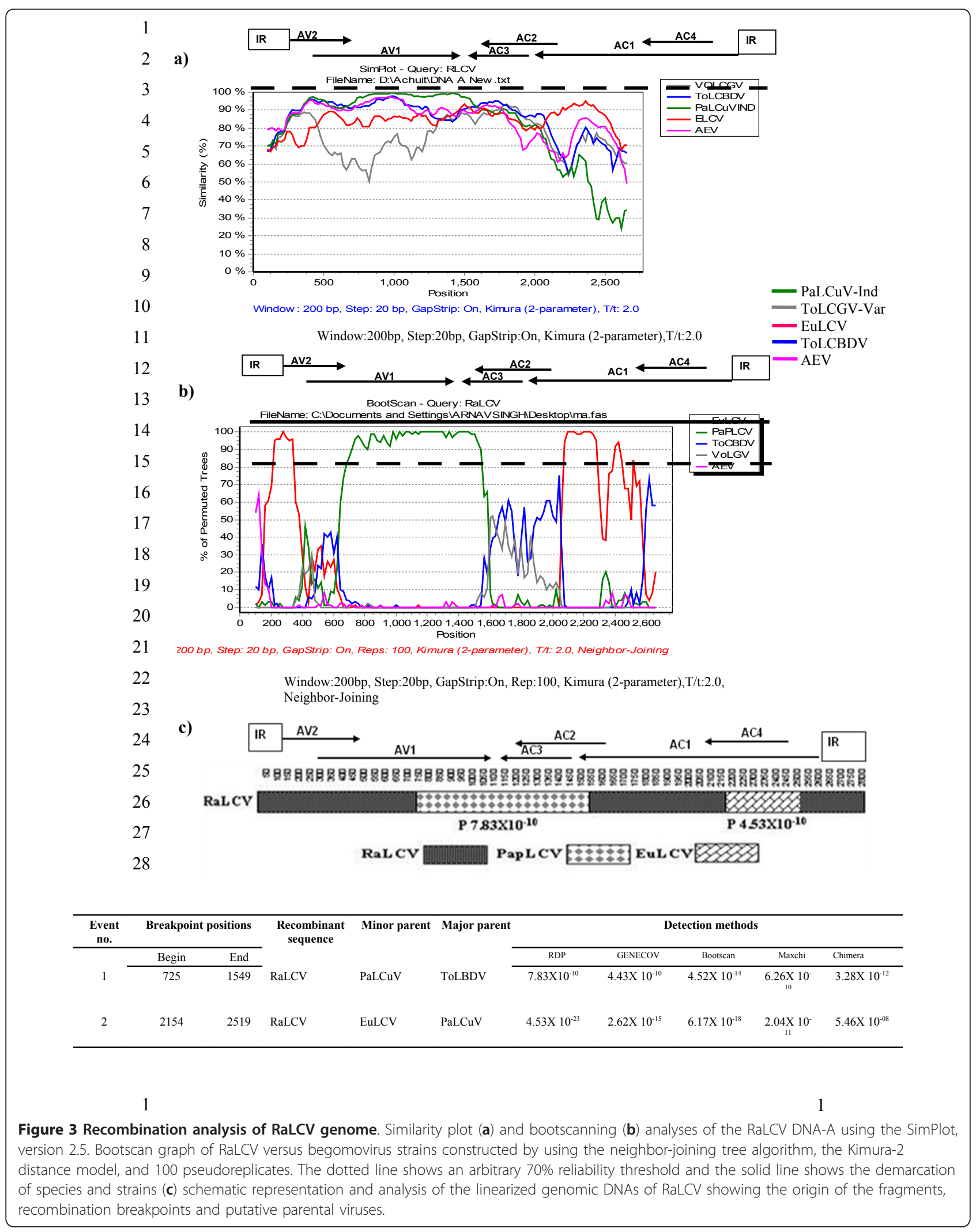


(Figure 4a, b; Table 3), however, RLA inoculated plants exhibited milder and delayed ( 6 days) symptoms as compared to infection by RLA + RL $\beta$ (Figure 4a; Table 3). Similarly, radish plants co-inocluated with CRA + CR $\beta$ exhibited severe leaf curling, twisting of petiole and enations symptoms (Figure 4a, d; Table 3), while CRA inoculated plants showed delayed (7 days) and milder symptom (Figure 4Ac; Table 3). The symptoms observed under experimental studies on radish plants were very similar to those observed under field conditions. The presence of viral genomic DNA and DNA betasatellites in infected radish plants was confirmed by Southern blot (Figure 4b and 4c) and PCR analysis (results not shown).

Tomato plants agroinoculated with the RLA and RL $\beta$ did not develop any symptom (Figure $4 \mathrm{a}, \mathrm{b}$ ), whereas those co-inoculated with CRA and CR $\beta$ developed severe leaf curling and stunting symptoms. CRA infected plants produced systemic leaf curling on upper leaves and mild stunting at later stages (Figure 4;able 4), but when plants were co-inoculated with CRA and CR $\beta$ they were severely stunted (Figure 4; Table 4). Agroinoculation of infectious clones of RLA and CRA to $N$. benthamiana resulted in leaf curling, enations and mild stunting of test plants (Figure 4Aa1 and 4Ac1) followed by typical severe leaf curling, twisting of petiole, interveinal chlorosis, severe stunting and enations on underside of leaves when co-inoculated with RL $\beta$ and CR $\beta$, respectively (Figure 4Ab1 and 4Ad1; Table 4). Presence of viral genomic DNA and DNA $\beta$ s in infected $N$. benthamiana and tomato were confirmed by Southern blot (Figures 4D, E, 5a and 5b) and PCR analysis (results not shown). Accumulation of DNA component (RLA and CRA) was enhanced when DNA betastaellite was associated.

Studies to determine whether RL $\beta$ is trans-replicated by CRA and vice versa, agroinoculation experiments were conducted. Results suggested that RL $\beta$ could be transreplicated by CRA and plants co-infected with CRA and RL $\beta$ develop severe leaf curling, leaf crinkling, interveinal chlorosis, enation on underside of leaves and severe stunting (Table 4). Similarly, RLA could also trans-replicate with CR $\beta$ and this combination produce distinct symptoms in $N$. benthamiana. Therefore, both the DNA $\beta$ s could be replicated by each other helper begomovirus leading to severe symptom phenotype (Table 4).

\section{RLA and CRA do not transreplicate DNA-B component of ToLCNDV and ToLCGV}

Co-inoculation of RLA and CRA with either DNA-B of ToLCNDV (NB) or ToLCGV (VB) did not influence symptom severity nor the time required for symptom appearance (Figure 6a-a1, 6b-b1, f-f1 and 6g-g1; Table 4). Thus, the symptom expression pattern was similar as observed in plants inoculated with RLA and CRA alone. In addition, presence of DNA-B could not be ascertained for both the cases (Figure 4D-E and $5 \mathrm{~d}$ ). It is relevant to mention here that iteron sequences are different among RLA, CRA with both the DNA-B components of tomato-infecting begomoviruses. This could be a barrier for efficient transreplication of the heterologous DNA-B component.

\section{$\mathrm{RL} \beta$ and CR $\beta$ can be a substitute for DNA B of either ToLCNDV or ToLCGV}

ToLCNDV is a bipartite begomovirus that requires both DNA components for systemic infection [27]. Tomato plants inoculated with DNA-A (NA) and DNA-B (NB) of ToLCNDV developed leaf curling within $8 \mathrm{dpi}$ and later the infected plants showed stunted growth along with severe leaf curling (30 dpi) (Figure 6q1), whereas tomato plants inoculated with only DNA-A remained symptomless (Table 4). Plants inoculated with NA alone lacked detectable levels of DNA in the newly emerged leaves when analyzed by PCR and Southern blot at 30 dpi (data not shown). To test whether a DNA betasatellite could influence the pattern of NA infection, tomato plants were inoculated with a mixture of NA + RL $\beta$ or $\mathrm{NA}+\mathrm{CR} \beta$. A proportion (58\%) of plants inoculated with NA + RL $\beta$ showed initial leaf curling (18 dpi) that later turned into pronounced leaf curling and enations at $30 \mathrm{dpi}$ (Figure 6d1, Table 4). Southern blot hybridization confirmed the presence of replicative forms of both NA and RL $\beta$ in the distal leaves of symptomatic plants (Figure 4E lane 6 and G). However, accumulation of NA was lower in these plants as compared to plants inoculated with NA + NB (Figure 4G). Interestingly, NA + CR $\beta$ inoculated tomato plants remain symptomless and newly emerging leaves lacked detectable levels of either $\mathrm{NA}$ or CR $\beta$ (Figures $5 \mathrm{~b}-\mathrm{c}$ and 6i1.). $N$. benthamiana plants inoculated with NA + RL $\beta$ showed distinguishable symptoms like typical downward leaf curling, interveinal chlorosis and twisting of petiole (Figure 6d), whereas NA + CR $\beta$ induced leaf curling, twisting of petiole and leaf puckering (Figure 6i). Accumulation of viral DNA (NA) was less $(\sim 51 \%)$ in plants inoculated with NA + RL $\beta$ or NA + CR $\beta$ as compared to those inoculated with homologous combination $(\mathrm{NA}+\mathrm{NB})$ (Figures 4F and 5c). Hence, RL $\beta$ and CR $\beta$ could support efficient movement of NA in $N$. benthamiana. However, CR $\beta$ cannot facilitate efficient movement of NA on tomato unlike RLB.

ToLCGV is a mono-bipartite species [28,29] and DNA-A (VA) alone is capable of causing systemic infection on $N$. benthamiana and tomato, although association of DNA-B results in increased symptom severity $[28,29]$. Neither RL $\beta$ nor CR $\beta$ could enhance systemic accumulation of VA as compared to VA + VB (Figures 


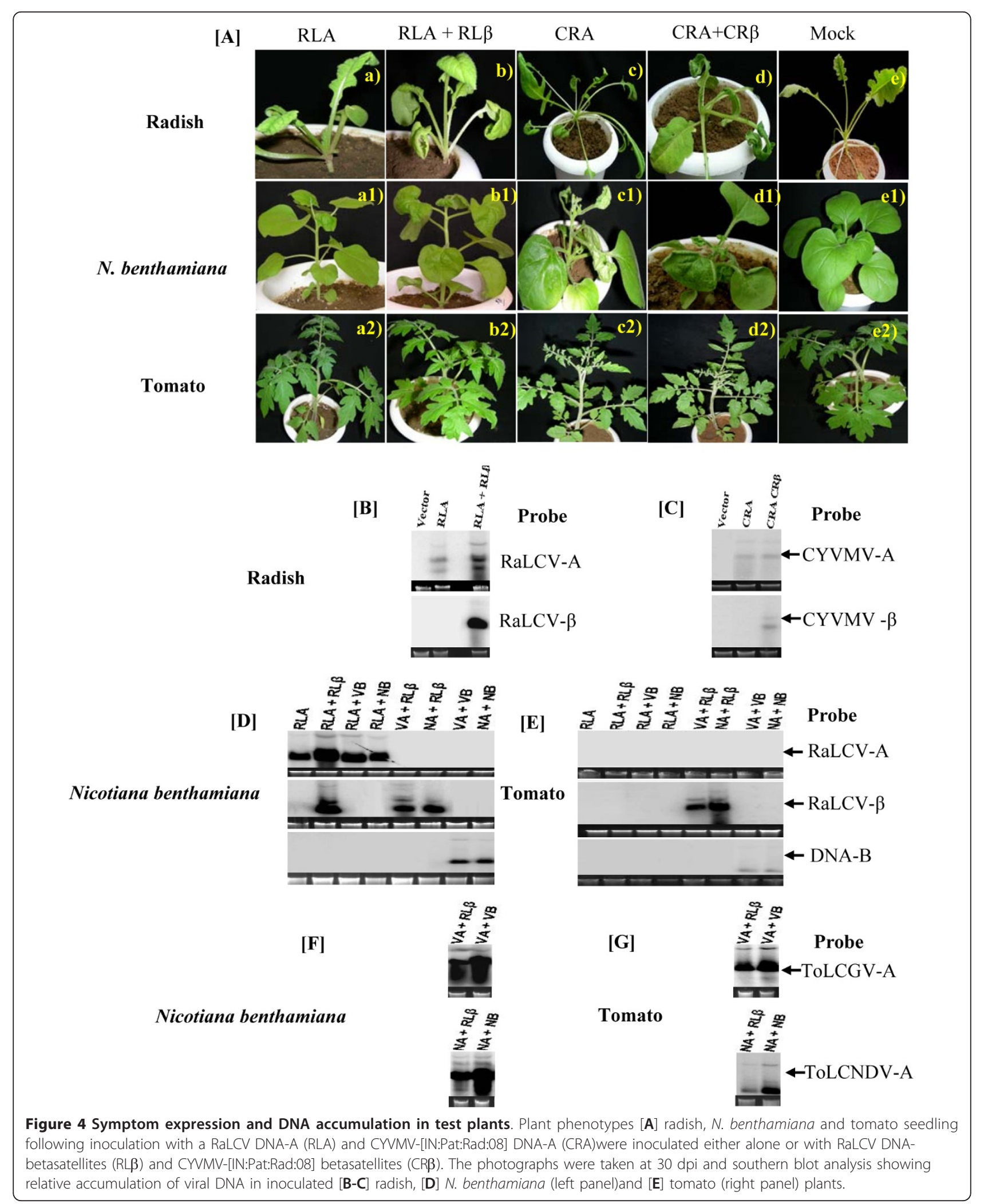


Table 3 Infectivity of viral genome and DNA betasatellites on radish plants

\begin{tabular}{|c|c|c|c|c|}
\hline $\begin{array}{l}\text { Test plant } \\
\text { (s) }\end{array}$ & $\begin{array}{l}\text { Construct combination used for } \\
\text { agroinoculation }\end{array}$ & $\begin{array}{l}\text { Plants showed symptom/Plants } \\
\text { inoculated }\end{array}$ & Symptom & $\begin{array}{l}\text { First symptom appearance } \\
\text { (dpi) }\end{array}$ \\
\hline \multirow[t]{6}{*}{ Radish } & RLA & $11 / 20$ & MLC & 26 \\
\hline & $R L A+R L \beta$ & $15 / 20$ & SL, LC, Ens & 20 \\
\hline & CRA & $12 / 20$ & $\mathrm{MLC}, \mathrm{LR}$ & 24 \\
\hline & $C R A+C R \beta$ & $17 / 20$ & $\begin{array}{l}\text { LC, St, Ens, } \\
\text { Tw }\end{array}$ & 17 \\
\hline & $\overline{V A+V B}$ & $0 / 16$ & & \\
\hline & $N A+N B$ & $0 / 16$ & & \\
\hline
\end{tabular}

RLA, RaLCV; RL $\beta$, RaLCB; CRA, CYVMV; CRß, CroYVMB; NA, ToLCNDV DNA-A; NB, ToLCNDV DNA-B; VA ToLCGV-DNA-A; VB, ToLCGV-DNA-B; MLC mild leaf curling; SL small leaves; $L C$ leaf curling; Ens enation; $L R$ Leaf rolling; $T w$ twisting of petiole

4F-G, and 5e), although inoculated plants exhibited severe symptom (Table 4). For example, in $N$. benthamiana, presence of either RL $\beta$ or CR $\beta$ alongwith VA together caused twisting of the petiole, interveinal chlorosis and more stunting of the plants, while tomato plants exhibited stunting alongwith severe leaf curling as compared to plants inoculated with VA + VB or VA + CR $\beta$ (Figure 6c-c1, 6h-h1 and 6p-p1, Table 4).

\section{Synergism between CRA, ToLCNDV and ToLCGV}

Since, CRA + CR $\beta$ could infect tomato and produced distinct symptoms like leaf curling, enation etc. (Table 4), we tested the potential consequences/interaction of these molecules with two predominant tomato-infecting begomoviruses (ToLCNDV and ToLCGV) from northern India. For this, tomato and $N$. benthamiana plants were inoculated with various combinations of viral DNA (Table 4). Plants inoculated with heterologous combinations of begomovirus species showed unusually severe symptoms as compared with plants infected with homologous combinations (CRA + CR $\beta$ or $\mathrm{VA}+\mathrm{VB}$ or $\mathrm{NA}+$ NB) (Figure 6e-q). More interestingly, symptom severity was enhanced whenever plants were inoculated with CRA + CR $\beta$ alongwith either NA or VA. For example, when CRA or CRA + CR $\beta$ were mixed with VA or NA or VA + VB or NA + NB, plants exhibited severe symptoms (Figure 6j-o). Plants inoculated with both components of any two virus species exhibited symptoms at least a day earlier than those inoculated with CRA + CR $\beta$ (Table 4). To investigate synergism at the level of viral DNA accumulation, Southern blot analysis was conducted with probes specific for each of the six DNA components (Figure 5). The level of CRA in plants inoculated with CRA + VA + CR $\beta$, CRA + NA + CR $\beta$, $\mathrm{CRA}+\mathrm{VA}+\mathrm{VB}$ and $\mathrm{CRA}+\mathrm{NA}+\mathrm{NB}$ was low in tomato as compared to $N$ benthamiana (Figure $5 \mathrm{a}$ ). However, the level of CRA was $\sim 1.4$ times higher when $\mathrm{VA}+\mathrm{VB}$ was also inoculated along with CRA + CR $\beta$ (Figure 5a), indicating CR $\beta$ assisted synergistic interaction. Unlike VA where no increase was observed, NA accumulation was marginally increased in plant inoculated with all four molecules (Figure $5 \mathrm{c}$ and $5 \mathrm{e}$ ). Interestingly, level of either VB or NB remained unchanged in plants inoculated with any of the following combinations $\mathrm{CRA}+\mathrm{VA}+\mathrm{VB}, \mathrm{CRA}+\mathrm{NA}+\mathrm{NB}, \mathrm{CRA}+\mathrm{VA}+$ $\mathrm{VB}+\mathrm{CR} \beta, \mathrm{CRA}+\mathrm{NA}+\mathrm{NB}+\mathrm{CR} \beta$ as compared to either VA $+\mathrm{VB}$ or NA $+\mathrm{NB}$, respectively (Figure $5 \mathrm{~d}$ and $5 f$ ). The level of CR $\beta$ was reduced by $53 \%$ and $42 \%$ when it was co-inoculated with VA and NA, respectively as compared with the wild-type combination (Figure $5 b)$. Accumulation of CR $\beta$ decreased upto $50-60 \%$ in plants inoculated with either CRA + VA + VB + CR $\beta$ or $\mathrm{CRA}+\mathrm{NA}+\mathrm{NB}+\mathrm{CR} \beta$, in comparison to plants inoculated with CRA + CR $\beta$ alone (Figure 5b). Together, these results indicate that CRA may interact synergistically with VA + VB in the presence of CR $\beta$.

\section{Discussion}

In India, radish was not considered as a host for begomoviruses till Singh et al. [24] reported association of a begomovirus with leaf curl disease from Varanasi region. Subsequently, RaLCD was also observed from Pataudi, a place located $\sim 800 \mathrm{~km}$ West from Varanasi. This indicates emergence of RaLCD as a new disease in India, incidence of which was recorded between 10-40\%. Here, we ascertain that RaLCD is caused by a complex of two Old World monopartite begomovirus species and two distinct betasatellite molecules. On the basis of genome organization and phylogenetic analysis, the virus from Varanasi region (RaLCV-[IN:Var:05]) is considered as a novel begomovirus species, which share maximum sequence identity $87.7 \%$ with ToLCBV-[BD], whereas virus from Pataudi share maximum sequence identity 95\% with CYVMV-IN and is considered as a CYVMVIN variant on the basis of DNA-A sequence identity criteria of ICTV [2]. Generally, begomovirus isolates sharing less than $89 \%$ nucleotide sequence identity are considered to be distinct species, sharing $90-92 \%$ are considered as new strain and those with more than $94 \%$ identity and are considered to be variant of that strain 
Table 4 Constructs, their infectivity and symptoms induced on agroinoculated plants

\begin{tabular}{|c|c|c|c|c|}
\hline $\begin{array}{l}\text { Test plant } \\
\text { (s) }\end{array}$ & $\begin{array}{l}\text { Construct combination used for } \\
\text { agroinoculation }\end{array}$ & $\begin{array}{l}\text { Plants showed symptom/Plants } \\
\text { inoculated }\end{array}$ & Symptom & $\begin{array}{l}\text { First symptom } \\
\text { appearance (dpi) }\end{array}$ \\
\hline \multirow{6}{*}{$\begin{array}{l}\mathrm{N} . \\
\text { benthamiana }\end{array}$} & RLA & $7 / 16$ & LC, Ens & 20 \\
\hline & $\overline{R L A}+R L \beta$ & $12 / 16$ & LC, Ens, IVCL, Tw, Bls & 8 \\
\hline & $\mathrm{RLA}+\mathrm{VB}$ & $5 / 16$ & LC, Ens & 20 \\
\hline & $\overline{R L A+N B}$ & $5 / 16$ & LC, Ens & 20 \\
\hline & $V A+R L \beta$ & $16 / 16$ & $\begin{array}{l}\mathrm{LC}, \mathrm{IVCL}, \mathrm{CR}, \mathrm{LD}, \mathrm{St}, \mathrm{BLS}, \\
\mathrm{SL}\end{array}$ & 5 \\
\hline & $N A+R L \beta$ & $16 / 16$ & LC, IVCL, CR, St, BLs, SL & 7 \\
\hline \multirow[t]{6}{*}{ Tomato } & RLA & $0 / 16$ & - & - \\
\hline & $\overline{R L A}+\mathrm{RL} \beta$ & $0 / 12$ & - & - \\
\hline & $R L A+V B$ & $0 / 12$ & - & - \\
\hline & $\mathrm{RLA+NB}$ & $0 / 12$ & - & - \\
\hline & $\overline{V A+R L \beta}$ & $12 / 12$ & $\begin{array}{l}\text { SLC, CR, LD, St, BLs, SL, } \\
\text { LPk }\end{array}$ & 8 \\
\hline & $\overline{N A+R L \beta}$ & $7 / 12$ & $L C, C R, Y L, T W$ & 18 \\
\hline \multirow{15}{*}{$\begin{array}{l}\text { N. } \\
\text { benthamiana }\end{array}$} & CRA & $16 / 16$ & LC, Ens, Tw & 7 \\
\hline & $\mathrm{CRA}+\mathrm{CR} \beta$ & $16 / 16$ & LC, Ens, IVCL, Bls, St, SL & 6 \\
\hline & $\overline{C R A+V B}$ & $16 / 16$ & LC, Ens, Tw & 7 \\
\hline & $\overline{C R A+N B}$ & $16 / 16$ & LC, Ens, Tw & 7 \\
\hline & $C R A+R L \beta$ & $16 / 16$ & LC, Ens, IVCL, Bls, St, SL & 6 \\
\hline & $\overline{V A+C R \beta}$ & $16 / 16$ & LC, IVCL, BLs, Tw & 6 \\
\hline & $\mathrm{NA}+\mathrm{CR} \beta$ & $16 / 16$ & LC, MY, VC, Bls, & 6 \\
\hline & $\overline{C R A+V A+C R \beta}$ & $16 / 16$ & $\begin{array}{l}\text { LC, IVCL, CR, Ens, St, BLs, } \\
\text { Tw }\end{array}$ & 5 \\
\hline & $\mathrm{CRA}+\mathrm{NA}+\mathrm{CR} \beta$ & $16 / 16$ & LC, Bls, IVCL, Ens, Tw & 5 \\
\hline & $\overline{C R A+V A+V B}$ & $16 / 16$ & $\begin{array}{l}\text { LC, IVCL, CR, Ens, Chls, } \\
\text { BLs, SL, Tw }\end{array}$ & 5 \\
\hline & $\overline{\mathrm{CRA}+\mathrm{NA}+\mathrm{NB}}$ & $16 / 16$ & $\begin{array}{l}\mathrm{LC}, \mathrm{YL}, \mathrm{VB}, \mathrm{St}, \mathrm{Mt}, \mathrm{Bls}, \\
\text { IVCL, Ens }\end{array}$ & 5 \\
\hline & $C R A+V A+V B+\beta$ & $16 / 16$ & $\begin{array}{l}\text { LC, IVCL, Ens, LD, St, Bls, } \\
\text { SL, Tw }\end{array}$ & 5 \\
\hline & $\mathrm{CRA}+\mathrm{NA}+\mathrm{NB}+\beta$ & $16 / 16$ & $\mathrm{SL}, \mathrm{YL}, \mathrm{St}, \mathrm{LC}, \mathrm{Mt}, \mathrm{Tw}$ & 5 \\
\hline & $\overline{V A+V B}$ & $10 / 10$ & $\begin{array}{l}\text { LC, IVCL, CR, LD, Chls, Bls, } \\
\text { SL }\end{array}$ & 6 \\
\hline & $\mathrm{NA}+\mathrm{NB}$ & $10 / 10$ & $\mathrm{SL}, \mathrm{YL}, \mathrm{LC}, \mathrm{Mt}$ & 5 \\
\hline \multirow[t]{11}{*}{ Tomato } & CRA & $10 / 12$ & $L C, L R$ & 21 \\
\hline & $\mathrm{CRA}+\mathrm{CR} \beta$ & $12 / 12$ & $L C, L R, V C, S L$ & 18 \\
\hline & $\mathrm{CRA}+\mathrm{VB}$ & $10 / 12$ & $L C, L R$ & 21 \\
\hline & $\overline{\mathrm{CRA}+\mathrm{NB}}$ & $9 / 12$ & $L C, L R$ & 21 \\
\hline & $\overline{C R A+R L \beta}$ & $12 / 12$ & $L C, L R, V C, S L$ & 19 \\
\hline & $\overline{N A+C R \beta}$ & $0 / 12$ & - & - \\
\hline & $V A+C R \beta$ & $10 / 12$ & LC, MY & 9 \\
\hline & $C R A+V A+C R \beta$ & $12 / 12$ & LC, LR, VC, SL, MY & 9 \\
\hline & $\mathrm{CRA}+\mathrm{NA}+\mathrm{CR} \beta$ & $12 / 12$ & $L C, L R, V C, S L$ & 16 \\
\hline & $C R A+V A+V B$ & $12 / 12$ & $L C, L R, C R, Y L$ & 7 \\
\hline & $\mathrm{CRA}+\mathrm{NA}+\mathrm{NB}$ & $12 / 12$ & $\mathrm{LC}, \mathrm{LR}, \mathrm{VC}, \mathrm{SL}, \mathrm{YL}$ & 8 \\
\hline
\end{tabular}


Table 4 Constructs, their infectivity and symptoms induced on agroinoculated plants (Continued)

\begin{tabular}{lllll}
\hline$C R A+V A+V B+\beta$ & $12 / 12$ & $L C, L R, C R, Y L, S t$ & 7 \\
\cline { 2 - 5 }$C R A+N A+N B+\beta$ & $12 / 12$ & $L C, L R, V C, S L, Y L$ & 8 \\
\cline { 2 - 3 } & $10 / 10$ & $L C, C R, L R, Y L$ & 7 \\
\cline { 2 - 5 } & $10 / 10$ & $L C, C R, Y L$ & 8 \\
\hline
\end{tabular}

$L C$ leaf curling; $B V$ big veins; $M Y$ mild yellowing; $Y L$ yellow leaf lamina; St stunting; $L D$ leaf distortion; $V B$ vein banding; $M O$ severe mosaic; $L R$ leaf rolling; $B / s$ blistering; SL small leaves; CR leaf crinkling; IVCL interveinal chlorosis; Chls chlorotic spots; MiMO mild mosaic; Mt mottling; SYL severe yellow leaf lamina; Tw twisting of petiole VC vein clearing, LPk Leaf puckering, Ens enation

[2]. Betasatellites associated with either RaLCV-[IN: Var:05] or CYVMV-[IN:Pat:Rad:08] was > 78\% identical to TbLCB and CroYVMB, respectively, indicating they are isolates of previously described begomovirus associated betasatellite species [30]. Hence, betasatellites are designated as TbLCB-IN[IN:Var:Rad] and CroYVMB[IN:Pat:Rad:08], respectively, which is also in concurrent with results of the phylogenetic analysis (Figure 2).

A current consensus regarding the extent of begomovirus diversity holds that high frequency of recombination, pseudorecombination and mutation is leading to emergence of highly pathogenic viruses which in turn cause economically important diseases [31-33]. The begomovirus causing RaLCD in the Pakistan can infect cotton and is strain of CLCuV [23]. However, in the present investigation, radish-infecting begomoviruses could not infect and produce symptom on cotton till 60 dpi. This is the first demonstration of Koch's postulates of radish-infecting begomoviruses, one of which is predominantly associated with infection on weed host, Croton. In the context of begomovirus emergence, it has been suggested that indigenous viruses infecting weed and wild hosts had been transferred to the new host, which facilitates emergence of novel species through recombination and/or pseudorecombination events [31-33]. Several new begomovirus species isolated and identified have arisen by recombination $[28,34]$.

Recombination can provide selective advantage in the evolution of viruses at species, genera and family levels and has been documented in both animal and plant viruses with RNA or DNA genomes [35-37]. In this study, recombination was detected among full-length DNA-A component of one of these newly identified radish-infecting begomovirus species and it's near relatives by RDP analysis. The pattern of recombination and position of breakpoints is very convincing and supports earlier study about pattern of recombination in geminiviruses [32,38]. Breakpoint was detected in the virion sense ORF AV1/AV2, in RaLCV-[IN:Var:05] genome and for this region it shared maximum identity with PaLCuV. ORFs AC2 and AC3 of RaLCV-[IN:Var:05] also shares maximum identity for this region with PaLCuV. In the rep-coding region, recombination was found with a weed infecting begomovirus most similar to EuLCV. This region is commonly exchanged among begomoviruses [38] and may provide a selective advantage, such as enhanced replication or suppression of host defense. It is apparent that RaLCV-[IN:Var:05] is a chimeric molecule and has arisen by inter-specific recombination among EuLCV, PaLCuV and ToLCBDV. This result was also confirmed through Simplot analysis. Further, placement of RaLCV-[IN:Var:05] in a distinct phylogenetic tree with isolates of EuLCV, PaLCuV and ToLCBDV, monopartite begomoviruses from Asia supported this observation. These findings together indicate that recombination among begomoviruses is an important driving force in evolution of plant infecting begomoviruses with extending host range. An increasing number of monopartite begomoviruses has been reported in India in recent years, most of them are associated with DNA betasatellites molecules with evidences that some of them may have not evolved in the recent past [34].

Agroinoculation studies demonstrated that these monopartite viruses (RLA and CRA) can replicate autonomously and move systemically in their natural host (radish), and induce mild leaf curl symptoms. However, in the presence of DNA betasatellite, RLA or CRA induces these symptoms, which appear similar to those observed in the fields in Varanasi and Pataudi, India. Therefore, the RaLCD disease complex is caused by cognate association of DNA-A and DNA betasatellite. Prerequisite association of a begomovirus and satellite DNA- $\beta$ has also been found to be necessary for typical disease development [14,15,34]. However, association of begomovirus and betasatelite complex with RaLCD has been demonstrated for the first time. Inability of RLA or CRA to transreplicate DNA-B molecule from either ToLCGV or ToLCNDV is attributed due to difference in iteron sequences and Rep binding sites observed. However, a number of recent studies have demonstrated that Rep-mediated binding can be more relaxed than thought previously $[29,39]$. Increase in symptom pattern and severity associated with betasatellites could be due to a direct effect of the $\beta C 1$ protein on plant development $[40,41]$. Trans-complementation of RL $\beta$ and CR $\beta$ with CRA and RLA, respectively, revealed the promiscuous nature of betasatellite replication. This was further evidenced from the finding that two tomato-infecting 


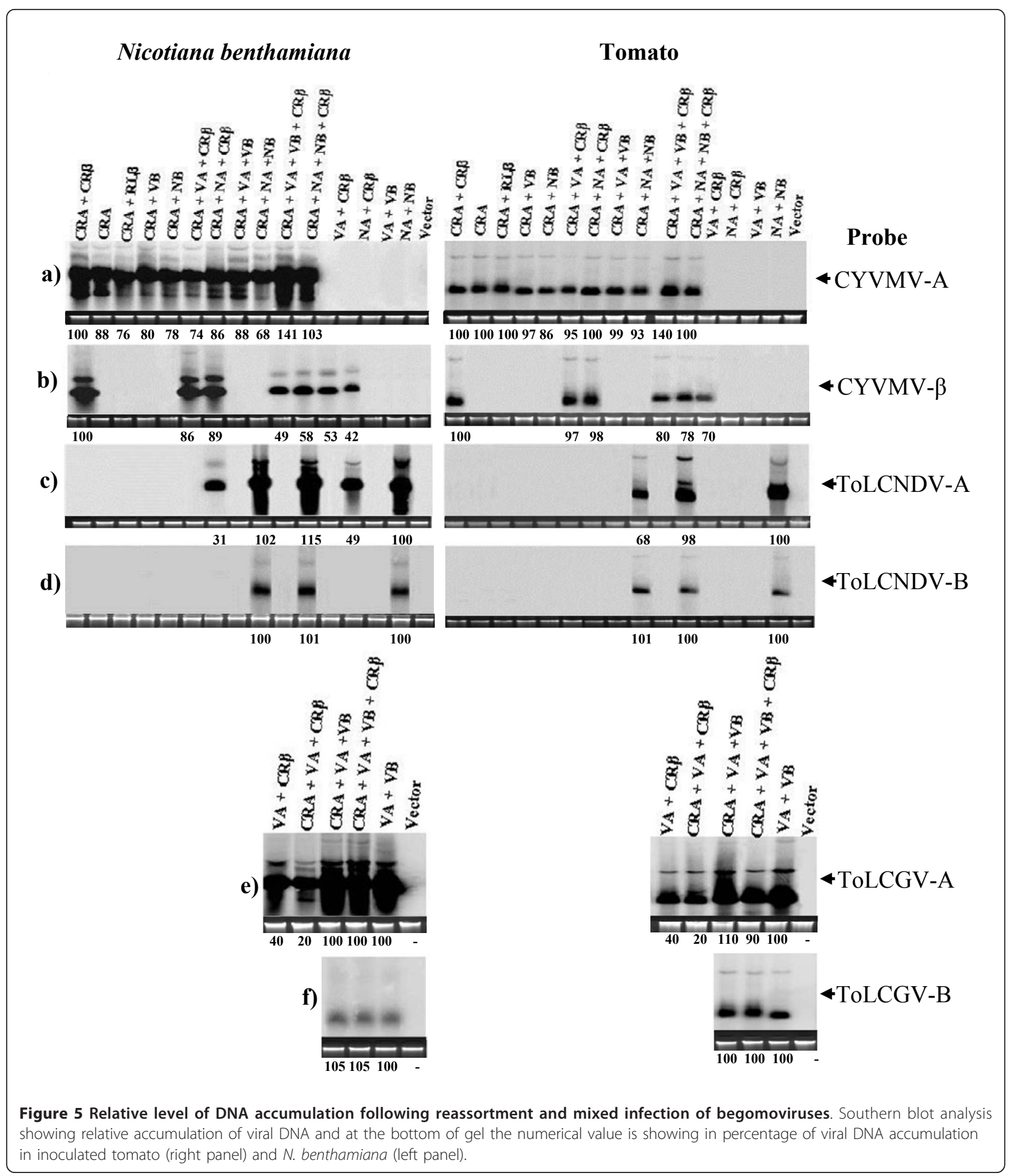

begomovirus species (ToLCGV[IN:Var:01] and ToLCNDV[IN:Svr:93]) also served as helper viruses for RL $\beta$ and CR $\beta$ in $N$. benthamiana [42-45]. Our results also show that betasatellites complement the functions of the DNA-B component of tomato-infecting begomoviruses (ToLCGV and ToLCNDV), by mobilizing DNA-A from sites of inoculation to the distal tissues. These results fortify the idea that the $\beta C 1$ protein can functionally substitute the role of DNA-B movement proteins [46]. 


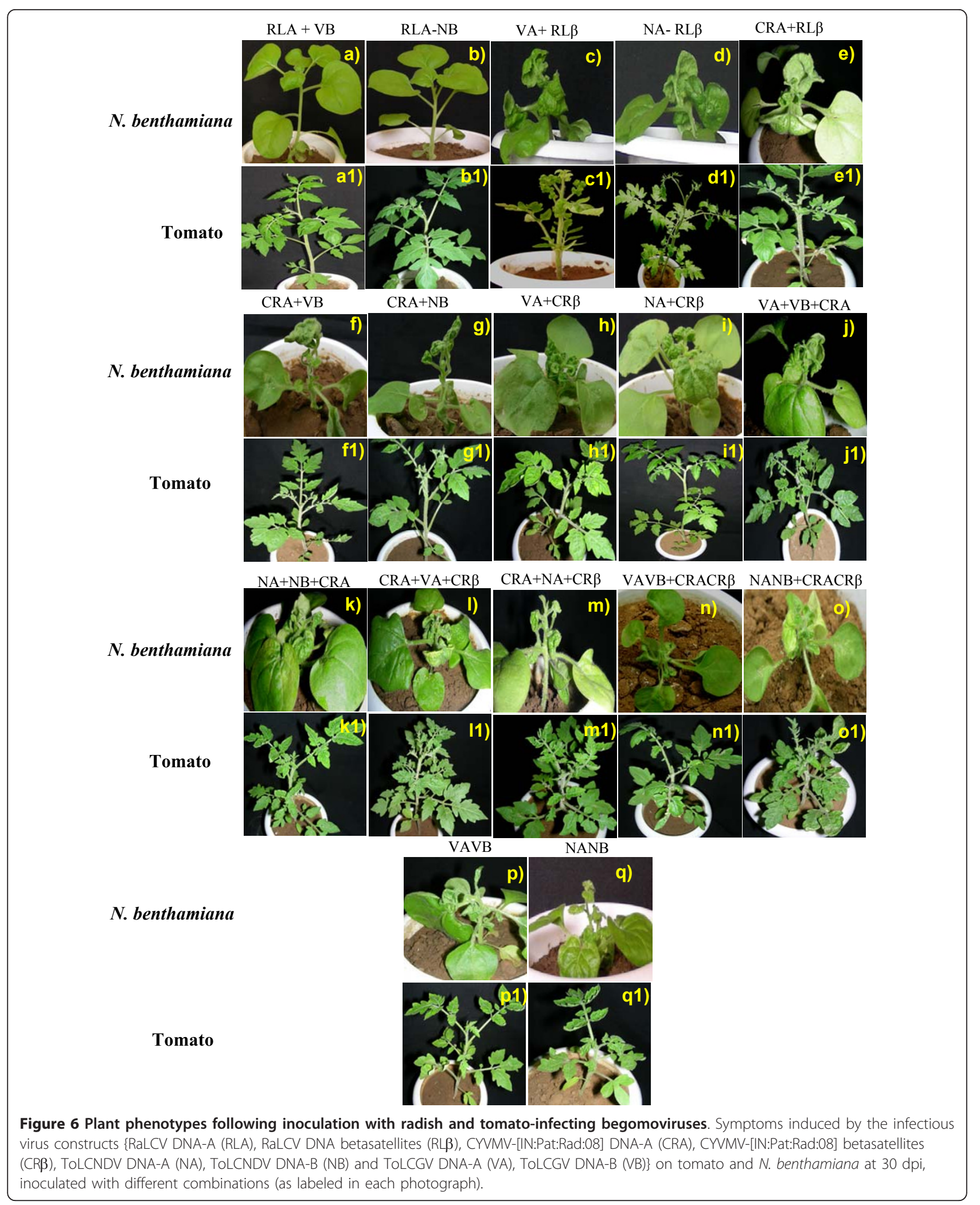


Mixed infection of begomoviruses is common in Indian sub-continent and situation is further worsened owing to ability of whiteflies to transmit more than one begomovirus species under field conditions $[47,48]$. Since, Croton yellow vein mosaic virus and betasatellite DNA, isolated from RaLCD infected plant could infect tomato, we further extended study to test interaction of CRA and CR $\beta$ with predominant tomato-infecting begomoviruses species (ToLCNDV and ToLCGV) from India. Plants ( $N$. benthamiana and tomato) inoculated with mixtures of either combinations of CRA + VA + $\mathrm{CR} \beta, \mathrm{CRA}+\mathrm{NA}+\mathrm{CR} \beta, \mathrm{CRA}+\mathrm{VA}+\mathrm{VB}, \mathrm{CRA}+\mathrm{NA}$ $+\mathrm{NB}, \mathrm{CRA}+\mathrm{VA}+\mathrm{VB}+\mathrm{CR} \beta$ and $\mathrm{CRA}+\mathrm{NA}+\mathrm{NB}+$ $\mathrm{CR} \beta$, produced severe symptoms compared with plants infected with isolates of only one begomovirus species. Viral DNA accumulation (CRA) was also slightly enhanced in plants inoculated with CRA + VA + VB + $\mathrm{CR} \beta$ or CRA + NA + NB + CR $\beta$ inoculated plants compared to plants inoculated with CRA + CR $\beta$. Interestingly, beta satellite accumulation was decreased (upto $60 \%$ ) in the presence of DNA-B component (either NB or $\mathrm{VB}$ ) in the above combinations tested. This is in concurrent with earlier observation [49]. No significant increase of DNA accumulation of NA or VA was observed while increase of CRA in dual infected plants indicates asymmetric synergism (Figure 5). Asymmetric synergism has earlier been reported among two tomatoinfecting begomoviruses [29].

\section{Conclusion}

RaLCD in India is caused by association of two monopartite begomoviruses and promiscuous betasatellites. This is also the first experimental demonstration of Koch's postulate for begomoviruses associated with leaf curl disease of radish. The aetiology of this disease and the capacity of the DNA- betasatellite to be replicated by other begomovirus species increase the possibility of recombination and reassortment events. This could lead to evolution of new recombinant viruses or begomovirus complexes with different biological properties. It is also possible that exchange of betasatellites (RaLCV associated with TbLCB satellite DNA- $\beta$ ) could extend the virus host range thereby emergence of new diseases in cultivated crop plants (for example tomato, radish). The persistence of promiscuous betasatellites, such as RL $\beta$ and CR $\beta$ in radish or other hosts like weeds (e.g. Croton spp.) could facilitate the emergence of highly pathogenic begomovirus/betasatellite complexes that may induce more severe diseases by overcoming natural resistance of hitherto non-host.

\section{Methods}

\section{Sample collection, grafting and DNA extraction}

Surveys of radish-growing areas of Varanasi, Uttar Pradesh and Pataudi, Haryana in India were conducted and infected radish plants showing typical virus infection symptoms (stunted and distorted growth and leaf curl) were collected. The leaves alongwith petioles of at least 1-1/2 in. long were cut from the symptomatic plants and were used as scion. Infected scions were grafted onto the healthy radish leaf petiole, known as stock. Grafted plants were kept within an insect-proof glass house. Total nucleic acids were extracted from collected samples [50].

\section{Viral DNA detection and cloning}

General detection of begomovirus association was carried out by Southern hybridization using coat protein probe [29] and by PCR with degenerate begomovirus specific primers [25]. PCR amplified DNA fragments were cloned into the $\mathrm{pTZR} 57 \mathrm{R} / \mathrm{T}$ vector (Fermentas Inc, USA) and sequenced. To facilitate full-length cloning of RaLCV-Varanasi genomic component (DNA-A), unique restriction site Nde I was determined, around which primer pairs RINdeIFP (5'CATATGTGAGCCGTGTTG3') and RINdeIRP (5'CATATGGGCTGTCGAAGT3') were designed.

For cloning of RaLCV-Pataudi, Haryana samples, viral DNA were amplified using Phi 29 DNA polymerase (Temphilphi; GE Healthcare) according to manufacturer's instruction. Briefly, the amplified concatemers were digested with restriction endonucleases to yield presumed monomeric virus components of $\sim 2.8 \mathrm{~kb}$. Potentially, full-length linearized viral genomes (at Bam $\mathrm{HI}$ site) were cloned into $\mathrm{pKS}^{+}$vector.

DNA-B degenerate primers [25] were used to amplify DNA-B component. The inability to amplify DNA-B using specific primer led us to design new set of primers corresponding to the common region shared by DNA-A and DNA-B followed by restriction endonuclease digestion of purified super-coiled DNA to identify two populations of molecules. Presence of betasatellite molecules was detected by PCR with primers beta01/02 [26]. Amplified products $(\sim 1.3 \mathrm{~kb})$ were cloned into pTZR57R/T vector (Fermentas Inc, USA).

\section{Sequence comparisons}

Putative full-length clones were purified using a Qiagen plasmid miniprep kit (Qiagen) and their sequences were determined commercially (Chromous Biotech, India). The sequence results were analyzed by comparing the sequence to other begomovirus sequences in GenBank using BLAST, followed by analysis using MEGA program version 4 (http://www.megasoftware.net/mega4/ features.html) [51] with default parameters. The fulllength genome sequences of representative begomoviruses and betasatellites were aligned using ClustalW and dendogram was generated using 1000 bootstrap repetitions. Standard abbreviations and GenBank 
accession numbers for DNA-A [2] and DNA betasatellites [30] were used.

\section{Recombination analysis}

Detection of potential recombinant sequences, identification of likely parental sequences, and localization of recombination breakpoints were carried out with the recombination detection program (RDP version 3) [52]. Default RDP settings were used throughout with a Pvalue cutoff of 0.01 and the standard Bonferroni correction. For bootscan analysis, 200 replicates with a $95 \%$ cut-off were taken, and for GENECONV analysis, the gscale parameter was set to 1 . In addition, both the viral genome and DNA betasatellites sequences were analysed using Simplot program, version 3.2 (http://sray.med.som. jhmi.edu/SCRoftware/Simplot), with a sliding window of 200 nucleotides moving in 20-nucleotide steps [53-55].

\section{Generation of constructs for infectivity studies}

To check infectivity, begomovirus and betasatellite were cloned as partial tandem repeat in pCAMBIA2301. For RaLCV-Var, 1.6 kb Bam HI (152)-Eco RI (1789) fragment containing the intergenic region (IR) was cloned to generate a 0.6 mer (pRLAV0.6). The full-length monomer was cloned into the Bam HI digested pRLAV0.6 to generate a 1.6 mer tandem repeat called pRLAV1.6 (referred to here as RLA). For RaLCV-Patudi, a $2.4 \mathrm{~kb} \mathrm{Bam} \mathrm{HI-Hind} \mathrm{III} \mathrm{fragment} \mathrm{containing} \mathrm{the} \mathrm{IR}$ was cloned to generate 0.8 mer (pCRAP0.8). The fulllength monomer was cloned into the Bam HI digested pCRAP0.8 to generate 1.8 mer tandem repeat called pCRAP1.8 (referred to here as CRA).

For the RaLCB-Var, Pst I (56)-Kpn I (1298) fragment was cloned into pCAMBIA2301, followed by ligation of full-length $K p n$ I fragment to produce partial tandem repeat called $\mathrm{pRL} \beta \mathrm{V} 1$ (referred to here as RL $\beta$ ). For the RaLCB-Pat, Kpn I (1292)-Eco RI (330) 395 bp fragment was released from RaLCB-Pat DNA- $\beta$ and was cloned into pCAMBIA2301, followed by ligation of full-length $K p n$ I fragment to produce 1.3 mer tandem repeat called pCR $\beta$ P1.3 (referred to here as CR $\beta$ ). Insert orientation within partial tandem repeats were confirmed by restriction digestion with appropriate enzymes.

\section{Infectivity and trans-complementation of cloned DNAs}

Recombinant plasmids (RLA, RL $\beta$, CRA and CR $\beta$ ) and the 'empty' vector (used as negative control) were introduced into Agrobacterium tumefaciens strain EHA105 by transformation. Agro-inoculation was performed in radish (cv Japanese White), Nicotiana benthamiana and tomato plants. Young seedlings (3-4 leaf stage) were inoculated viral constructs either alone or in combination by needle puncture method.
Trans-complementation with genomic components of tomato-infecting begomoviruses (Tomato leaf curl New Delhi virus [ToLCNDV] and Tomato leaf curl Gujarat virus [ToLCGV]) [32] was also studied. Agrobacterium cultures containing respective constructs (Table 4) were mixed in equal concentration and inoculated into test plants. The inoculated plants were placed in a controlled growth chamber with $16 \mathrm{~h}$ day light at $28^{\circ} \mathrm{C} / 70 \%$ relative humidity. All the experiments were repeated at least for four times and symptom progression was recorded till 45 dpi.

\section{Detection of viral DNA}

Total genomic DNA was extracted from leaf tissue at 30 dpi following Dellaporta method [50]. Viral and satellite DNAs was detected by PCR with the specific primers for RLA (RLF1.3 5'CTGGGCTTACCCATAGAGTGG3' \& RLR1.3 5'CAGGGAAGACAATGTGGGCCT3'), CRA (CRF0.9 5'ATGGGTCTCTGCATATCCATGCCCTC3' \& CRR0.9 5'TCAACTCGTCGACGCCTGATCCC TTTC3'), (RLBF 5'ATGACGATCAAATACAAAAACCAGAAAG3' RLBR 5'TTATACAGATGA ACGCGTATACACATCG3') CR $\beta$ (CrßF 5'ATGACGATCATA TATCAGAATGAGAC \& CrßR 5'TTACACATTTACATATTTAGACACATC3'). In addition, specific primers were used for detection of genomic components of ToLCGV and ToLCNDV following Chakraborty et al. [29].

For southern hybridization analysis, total genomic DNA $(8 \mu \mathrm{g})$ was separated on agarose gel (1\%) and transferred to Hybond-N+ membrane (Amersham GE Healthcare, UK), following standard procedures [56]. Viral DNA was detected by hybridizing blots separately using radiolabelled probes of DNA-A and DNA- betasatellites specific to either species. For RLA, a BseRI fragment (nt 2097-2616) and for RL $\beta$ a EcoRI fragment (nt 299-506) was used as the probe. For CRA, a Pst I-Xba I (nt 14551884) fragment and for CR $\beta$ a EcoRI-Nde I fragment (nt 330-1041) were used. Specific probes for detection of DNA-A and DNA-B of ToLCNDV and ToLCGV were prepared according to Chakraborty et al. [29]. DNA fragments were labelled with $\left[\alpha-{ }^{32} \mathrm{P}\right] \mathrm{dCTP}$ by random oligonucleotide-primed synthesis [57]. Viral DNA levels were quantified using a PhosphorImager (Fuji Film).

\section{Acknowledgements}

The research work was supported by Capacity Build-up Grant of the University Grant Commission, UGC-CAS and UGC Resource Net working grant provided to SC by Jawaharlal Nehru University, New Delhi, India.

\section{Author details}

TMolecular Virology Laboratory, School of Life Sciences, Jawaharlal Nehru University, New Delhi 110 067, India. ${ }^{2}$ School of Life Sciences, Central University of Gujarat, Gandhinagar 382030, Gujarat, India. 


\section{Authors' contributions}

AKS performed the experiments. AKS, BC and SC were involved in data analysis experimental design and writing the manuscript. All the authors read and approved the final manuscript.

\section{Competing interests}

The authors declare that they have no competing interests.

Received: 2 August 2011 Accepted: 16 February 2012 Published: 16 February 2012

\section{References}

1. Stanley J, Bisaro DM, Briddon RW, Brown JK, Fauquet CM, Harrison BD, Rybicki EP, Stenger DC: Geminivirida. In Virus Taxonomy: Eighth Report of the International Committee on Taxonomy of Viruses. Edited by: Fauquet CM, Mayo MA, Maniloff J, Desselberger U, Ball LA. London: Elsevier/Academic Press; 2005:301-326.

2. Fauquet CM, Briddon RW, Brown JK, Moriones E, Stanley J, Zerbini M, Zhou X: Geminivirus strain demarcation and nomenclature. Arch Virol 2008, 153:783-821

3. Varma A, Malathi VG: Emerging geminivirus problems. A serious threat to crop production. Ann Appl Biol 2003, 142:145-164.

4. Rojas MR, Hagen C, Lucas WJ, Gibertson RL: Exploiting chinks in the plant's armor: evolution and emergence of geminiviruses. Annu Rev Phytopathol 2005, 43:361-394.

5. Seal SE, van den Bosch F, Jeger MJ: Factors influencing begomovirus evolution and their increasing global significance: implications for sustainable control. Cri Rev Plant Sciences 2006, 25:23-46.

6. Lazarowitz SG: Geminivirus: genome structure and gene function. Crit Rev Plant Sci 1992, 11:327-349.

7. Laufs J, Jupin I, David C, Schumacher S, Heyraud-Nitschke F, Gronenborn B: Geminivirus replication: genetic and biochemical characterization of Rep protein function, a review. Biochimie 1995, 77:765-773.

8. Sunter G, Hartitz MD, Hormudzi SG, Brough CL, Bisaro DM: Genetic analysis of tomato golden mosaic virus: ORF AL2 is required for coat protein accumulation while ORF AL3 is necessary for efficient DNA replication. Virology 1990, 179:69-77.

9. Stanley J: Infectivity of the cloned geminivirus genome requires sequences from both DNA. Nature 1983, 305:643-645.

10. Kheyr-Pour A, Bendahmane M, Matzeit V, Accotto GPM, Crespi S, Gronenborn B: Tomato yellow leaf curl virus: from Sardinia is a whiteflytransmitted monopartite geminivirus. Nucleic Acids Res 1991, 19:6763-6769.

11. Navot N, Pichersky E, Zeidan M, Zamir D, Czosnek H: Tomato yellow leaf curl virus: a whitefly-transmitted geminivirus with a single genomic component. Virology 1991, 185:151-161.

12. Dry IB, Rigden JE, Krake LR, Mullineax PM, Rezaian MA: Nucleotide sequence and genome organisation of tomato leaf curl geminivirus. J Gen Virol 1993, 74:147-151.

13. Briddon RW, Mansoor S, Bedford ID, Pinner MS, Markham PG: Clones of cotton leaf curl geminivirus induce symptoms atypical of cotton leaf curl disease. Virus Genes 2000, 20:17-24.

14. Briddon RW, Mansoor S, Bedford ID, Pinner MS, Saunders K, Stanley J, Zafar Y, Malik K, Markham PG: Identification of DNA components required for induction of cotton leaf curl disease. Virology 2001, 285:234-243.

15. Jose J, Usha R: Bhendi yellow vein mosaic disease in India is caused by association of a DNA $\beta$ satellite with a begomovirus. Virology 2003, 305:310-317.

16. Saunders K, Norman A, Gucciardo S, Stanley J: The DNA $\beta$ satellite component associated with ageratum yellow vein disease encodes an essential pathogenicity protein ( $\beta C 1$ ). Virology 2004, 324:37-47.

17. Cui $X$, Tao X, Xie Y, Fauquet CM, Zhou X: A DNA $\beta$ associated with tomato yellow leaf curl China virus is required for symptom induction. $J$ Virol 2004, 78:13966-13974.

18. Briddon RW, Stanley J: Subviral agents associated with plant singlestranded DNA viruses. Virology 2006, 344:198-210.

19. Kon T, Rojas MR, Abdourhamane IK, Gilbertson RL: Roles and interactions of begomoviruses and satellite DNAs associated with okra leaf curl disease in Mali, West Africa. J Gen Virol 2009, 90:1001-1013.
20. Saunders K, Bedford ID, Briddon RW, Markham PG, Wong SM, Stanley J: A unique virus complex causes ageratum yellow vein disease. Proc Natl Acad Sci USA 2000, 97:6890-6895.

21. Briddon RW, Bull SE, Amin I, Idris AM, Mansoor S, Bedford ID, Dhawan P, Rishi N, Siwatch SS, Abdel-Salam AM, Brown JK, Zafar Y, Markham PG: Diversity of DNA- $\beta$, a satellite molecule associated with some monopartite begomoviruses. Virology 2003, 312:106-121.

22. Zhou X, Xie Y, Tao X, Zhang Z, Li Z, Fauquet CM: Characterisation of DNAassociated with begomoviruses in China and evidence for co-evolution with their cognate viral DNA-A. J Gen Virol 2003, 84:237-247.

23. Mansoor S, Mukhtar S, Hussain M, Amin I, Zafar Y, Malik KA: Widespread occurrence of cotton leaf curl virus on radish in Pakistan. Plant Dis 2000, 84:80.

24. Singh AK, Chattopadhyay B, Pandey PK, Singh AK, Chakraborty S: A new Begomovirus species causing leaf curl disease of radish in India. Plant Dis 2007, 91:1053.

25. Rojas MR, Gillbertson RL, Russel DR, Maxwell DP: Use of degenerate primers in the polymerase chain reaction to detect whitefly-transmitted geminiviruses. Plant Dis 1993, 77:340-347.

26. Briddon RW, Bull SE, Mansoor S, Amin I, Markham PG: Universal primers for the PCR-mediated amplification of DNA- $\beta$ : a molecule associated with some monopartite begomoviruses. Mol Bio-technol 2002, 20:315-318.

27. Padidam M, Beachy RN, Fauquet CM: Tomato leaf curl geminivirus has bipartite genome and coat protein is not essential for infectivity. I Gen Virol 1995, 76:25-35.

28. Chakraborty S, Pandey PK, Banerjee MK, Kalloo G, Fauquet CM: Tomato leaf Gujarat virus, a new begomovirus species causing a severe leaf curl disease of tomato in Varanasi, India. Phytopathology 2003, 93:1485-1496.

29. Chakraborty S, Vanitharani R, Chattopadhyay B, Fauquet CM: Supervirulent pseudorecombination and asymmetric synergism between genomic components of two distinct species of begomovirus associated with severe tomato leaf curl disease in India. J Gen Virol 2008, 89:818-828.

30. Briddon RW, Brown JK, Moriones E, Stanley J, Zerbini M, Zhou X, Fauquet CM: Recommendations for the classification and nomenclature of the DNA- $\beta$ satellites of begomoviruses. Arch Virol 2008, 153:763-781.

31. Zhou X, Liu Y, Calvert L, Munoz D, Otim-Nape GW, Robinson DJ, Harrison BD: Evidence that DNA-A of a geminivirus associated with severe cassava mosaic disease in Uganda has arisen by interspecific recombination. J Gen Virol 1997, 78:2101-2111.

32. Padidam M, Sawyer S, Fauquet CM: Possible emergence of new geminiviruses by frequent recombination. Virology 1999, 265:218-225.

33. Pita JS, Fondong VN, Sangare A, Otim-Nape GW, Ogwal S, Fauquet CM: Recombination, pseudo-recombination and synergism of geminiviruses are determinant keys to the epidemic of the cassava mosaic disease in Uganda. J Gen Virol 2001, 82:655-661.

34. Kumari P, Singh AK, Sharma VK, Chattopadhyay B, Chakraborty S: A novel recombinant tomato-infecting begomovirus capable of transcomplementing heterologous DNA-B components. Arch Virol 2011, 156:769-783.

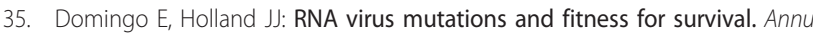
Rev Microbiol 1997, 51:151-178.

36. Harrison BD, Robinson DJ: Natural genomic and antigenic variation in whitefly-transmitted geminiviruses (begomoviruses). Annu Rev Phytopathol 1999, 37:369-398

37. Garci'a-Arenal F, Fraile A, Malpica JM: Variability and genetic structure of plant virus populations. Annu Rev Phytopathol 2001, 39:157-186.

38. Lefeuvre P, Lett JM, Reynaud B, Martin DP: Avoidance of protein fold disruption in natural virus recombinants. PLoS Pathog 2007, 7:1782-1789.

39. Andrade EC, Manhani GG, Alfenas PF, Calegario RF, Fontes EPB, Zerbini FM: Tomato yellow spot virus, a tomato-infecting begomovirus from Brazil with a closer relationship to viruses from Sida sp, forms pseudorecombinants with begomoviruses from tomato but not from Sida. J Gen Virol 2006, 87:3687-3696.

40. Qazi J, Amin I, Mansoor S, labal MJ, Briddon RW: Contribution of the satellite encoded gene $\beta C 1$ to cotton leaf curl disease symptoms. Virus Res 2007, 128:135-139.

41. Yang JY, Iwasaki M, Machida C, Machida Y, Zhou X, Chua NH: $\beta$ C1, the pathogenicity factor of TYLCCNV, interacts with AS1 to alter leaf development and suppress selective jasmonic acid responses. Genes Dev 2008, 22:2564-2577. 
42. Mansoor S, Briddon RW, Bull SE, Bedford ID, Bashir A, Hussain M, Saeed M, Zafar Y, Malik KA, Fauquet C, Markham PG: Cotton leaf curl disease is associated with multiple monopartite begomoviruses supported by single DNA- $\beta$. Arch Virol 2003, 148:1969-1986.

43. Mansoor S, Zafar Y, Briddon RW: Geminivirus disease complexes: the threat is spreading. Trends Plant Sci 2006, 11:209-212.

44. Saunders K, Briddon RW, Stanley J: Replication promiscuity of DNA- $\beta$ satellites associated with monopartite begomoviruses; deletion mutagenesis of the Ageratum yellow vein virus DNA- $\beta$ satellite localizes sequences involved in replication. J Gen Virol 2008, 89:3165-3172.

45. Nawaz-ul-Rehman MS, Mansoor S, Briddon RW, Fauquet CM: Maintenance of an Old World betasatellite by a New World helper begomovirus and possible rapid adaptation of the betasatellite. J Virol 2009, 83:9347-9355.

46. Saeed M, Zafar Y, Randles JW, Rezaian MA: A monopartite begomovirusassociated DNA $\beta$ satellite substitutes for the DNA B of a bipartite begomovirus to permit systemic infection. J Gen Virol 2007, 88:2881-2889.

47. Sanz Al, Fraile A, García-Arenal F, Zhou X, Robinson DJ, Khalid S, Butt T, Harrison BD: Multiple infection, recombination and genome relationships among begomovirus isolates found in cotton and other plants in Pakistan. J Gen Virol 2000, 81:1839-1849.

48. Yang C, Jia S, Liu Z, Cui G, Xie L, Wu Z: Mixed Infection of Two Begomoviruses in Malvastrum coromandelianum in Fujian, China. $J$ Phytopathology 2008, 156:553-555.

49. Patil BL, Fauquet CM: Differential interaction between cassava mosaic geminiviruses and geminivirus satellites. J Gen Virol 2010, 91:1871-1882.

50. Dellaporta SL, Wood J, Hicks JB: A plant DNA minipreparation. Version II. Plant Mol Biol Rep 1983, 1:19-21.

51. Tamura K, Dudley J, Nei M, Kumar S: MEGA4: Molecular Evolutionary Genetics Analysis (MEGA) Software Version 4.0. Mo Biol Evol 2007, 24:1596-1599.

52. Martin DP, Williamson C, Posada D: RDP2: recombination detection and analysis from sequence alignments. Bioinformatics 2005, 21:260-262.

53. Blawid R, Van DT, Maiss E: Trans-replication of a Tomato yellow leaf curl Thailand virus DNA-B and replication of a DNA- $\beta$ component by Tomato leaf curl Vietnam virus and Tomato yellow leaf curl Vietnam virus. Virus Res 2008, 136:107-117.

54. Bouslama L, Nasri D, Chollet L, Belguith K, Bourlet T, Aouni M, Pozzetto B, Pillet S: Natural recombination event within the capsid genomic region leading to a chimeric strain of human enterovirus. J Virol 2007, 81:8944-8952.

55. Lole KS, Bollinger RC, Paranjape RS, Gadkari D, Kulkarni SS, Novak NG, Ingersoll R, Sheppard HW, Ray SC: Full-length human immunodeficiency virus type 1 genomes from subtype C-infected seroconvertes in India, with evidence of intersubtype recombination. J Virol 1999, 73:152-160.

56. Sambrook J, Russell DW: Molecular Cloning: a Laboratory Manual. 3 edition. NY: Cold Spring Harbor, Cold Spring Harbor Laboratory; 2001.

57. Feinberg $A P$, Vogelstein $B: A$ technique for radiolabelling DNA restriction endonuclease fragments to high specific activity. Ann Biochem 1983 132:6-13.

doi:10.1186/1743-422X-9-43

Cite this article as: Singh et al:: Biology and interactions of two distinct monopartite begomoviruses and betasatellites associated with radish leaf curl disease in India. Virology Journal 2012 9:43.

\section{Submit your next manuscript to BioMed Central and take full advantage of:}

- Convenient online submission

- Thorough peer review

- No space constraints or color figure charges

- Immediate publication on acceptance

- Inclusion in PubMed, CAS, Scopus and Google Scholar

- Research which is freely available for redistribution

Submit your manuscript at www.biomedcentral.com/submit
Ciomed Central 